\title{
Differentiation of human parathyroid cells in culture
}

\author{
W Liu, P Ridefelt ${ }^{1}$, G Åkerström and P Hellman \\ Department of Surgery, University Hospital, Uppsala, Sweden \\ ${ }^{1}$ Clinical Chemistry, University Hospital, Uppsala, Sweden \\ (Requests for offprints should be addressed to P Hellman, Department of Surgery, University Hospital, SE-751 85 Uppsala, Sweden; \\ Email: Per.Hellman@kirurgi.uu.se)
}

\begin{abstract}
Continuous culture of parathyroid cells has proven difficult, regardless from which species the cells are derived. In the present study, we have used a defined serum-free low calcium containing medium to culture human parathyroid cells obtained from patients with parathyroid adenomas due to primary hyperparathyroidism. No fibroblast overgrowth occurred, and the human parathyroid chief cells proliferated until confluent. After the first passage the cells ceased to proliferate, but still retained their functional capacity up to 60 days, demonstrated by $\mathrm{Ca}^{2+}$-sensitive changes in the release of parathyroid hormone $(\mathrm{PTH})$ and as adequate cytoplasmic calcium $\left(\left[\mathrm{Ca}^{2+}\right]_{\mathrm{i}}\right)$ responses to changes in ambient calcium as measured by microfluorimetry. Low calcium concentrations enhanced, and vitamin $\mathrm{D}_{3}$ and retinoic acids (RA) dose-dependently inhibited cell proliferation during the first passage, as determined by $\left[{ }^{3} \mathrm{H}\right]$ thymidine incorporation, immuno-
\end{abstract}

histochemistry for proliferating cell nuclear antigen and cell counting. Signs of differentiation were present as the set-points, defined as the external calcium concentration at which half-maximal stimulation of $\left[\mathrm{Ca}^{2+}\right]_{\mathrm{i}}\left(\right.$ set-point $\left._{\mathrm{c}}\right)$, or half-maximal inhibition of PTH release (set-point p $_{\mathrm{p}}$ ) occur, were higher in not proliferating compared with proliferating cells in P0. Inhibition of cell proliferation was accompanied by signs of left-shifted set-points, indicating a link between proliferation and differentiation.

The results demonstrate that human parathyroid chief cells cultured in a defined serum-free medium can be kept viable for a considerable time, and that signs of differentiation occur after proliferation has ceased. The low calcium stimulated cell proliferation may also be inhibited by vitamin $\mathrm{D}$ and $\mathrm{RA}$.

Journal of Endocrinology (2001) 168, 417-425

\section{Introduction}

The parathyroid glands are the primary regulatory organs for maintenance of serum calcium concentration within a narrow physiological range (Brown 1991). The parathyroid chief cells are equipped with a cell surface-bound calcium-sensing mechanism, which regulates parathyroid hormone (PTH) release (Brown 1991). Abnormal parathyroid cells in parathyroid adenoma, hyperplasia or cancer, are characterized by decreased sensitivity to extracellular calcium concentrations, yielding inappropriate inhibition of PTH release, increased serum PTH levels and hypercalcemia (Hellman et al. 1994). This circumstance has been attributed to reduced cell surface expression of calcium sensing receptors (Juhlin et al. 1988, Kifor et al. 1996). Most documentation of calcium sensing in parathyroid cells relates to the $120 \mathrm{kDa}$ 'calcium sensing receptor', CaR (Brown et al. 1993). However, even though both CaR protein and mRNA levels are reduced in parathyroid adenomas compared with normal glands of the same patient, no correlation between the reduction in $\mathrm{CaR}$ expression and serum $\mathrm{Ca}^{2+}$ or PTH levels has been found (Farnebo et al. 1997). There may also be other calcium receptors, e.g. the $550 \mathrm{kDa}$ glycoprotein LRP2/ megalin which has been proposed as expressing a calcium sensing function (Juhlin et al. 1987, Christensen et al. 1992, Hjälm et al. 1996).

The reduced calcium sensing function as well as calcium receptor expression seen in adenomatous and hyperplastic cells have been attributed to various degrees of functional dedifferentiation (Juhlin et al. 1988, Kifor et al. 1996). Bovine parathyroid cells seem to present a model for this phenomenon, since they dedifferentiate during culture up to 5-7 days, whereby expression of $\mathrm{CaR}$ is reduced, and the calcium sensing function gradually impairs (Kifor et al. 1996). However, success with continuous culture of bovine cells has in our (and many other) hands been limited by the overgrowth of fibroblasts after 5-10 days, although there are reports in the literature describing successful culture involving an impressive number of doublings (Brandi et al. 1986). Also, there seems to be a difference between bovine and human parathyroid cells, since CaR expression in the latter is retained in culture (Roussanne et al. 1998). 
Vitamin $\mathrm{D}_{3}$ has an important regulatory role in the parathyroid. Mediated by binding to its receptor (VDR), inhibition of PTH gene transcription and proliferation occurs (Demay et al. 1992, Naveh-Many et al. 1995). The effect of vitamin $\mathrm{D}_{3}$ is the rationale for treatment of hyperparathyroidism secondary to uremia with vitamin $\mathrm{D}_{3}$ in vivo, resulting in lowering of serum PTH levels as well as signs of reduced tumor progression (Slatopolsky et al. 1984). In addition, it is evident that parathyroid cells are targets for retinols and retinoic acids, since metabolic conversion of retinol to retinoic acids take place in parathyroid cells, and that these compounds can reduce mRNA levels as well as the release of PTH (MacDonald et al. 1994, Liu et al. 1996).

To further study the effects of external calcium, vitamin $\mathrm{D}$ and retinoids, and their possible relation to the differentiation level in human pathological parathyroid cells, human parathyroid cell cultures are needed. There is only one report documenting successful long-term human parathyroid cultures, and the only cell line reported to be derived from parathyroid cells is of rat origin and does not produce PTH (Sakaguchi et al. 1987, Roussanne et al. 1998). In this report we describe one model that enables studies of cell proliferation and calcium sensing in human parathyroid cells derived from adenomas cultured in a serum-free medium. For the first time we can demonstrate signs of induced differentiation in parathyroid cells, by coupling increased sensitivity to external $\mathrm{Ca}^{2+}$ to reduced proliferation. We also demonstrate effects of vitamin $\mathrm{D}_{3}$ and retinoic acid on sensitivity to external $\mathrm{Ca}^{2+}$ (differentiation) and proliferation of the cultured pathological parathyroid cells.

\section{Materials and Methods}

\section{Cell culture}

Biopsies of 10 human parathyroid adenomas were obtained during surgery of patients with primary hyperparathyroidism (HPT). This procedure was approved by the local Ethics committee. The patients $(7$ females, 3 males, mean age $69 \pm 12$ years) had sporadic non-familial primary HPT, total albumin-corrected serum $\mathrm{Ca}^{2+}$ ranging from 2.69 to $3.12 \mathrm{mmol} / 1$ (mean $2.82 \pm 0.07 \mathrm{mmol} / \mathrm{l}$; reference range $2 \cdot 20-2.60 \mathrm{mmol} / 1$; orthocresolphthalein method) and intact serum PTH of between 58 and $110 \mathrm{ng} / \mathrm{l}$ (mean $72 \pm 5 \mathrm{ng} / \mathrm{l}$; reference range 12-55 ng/l; Nichol's Institute, San Capistrano, CA, USA). The glands were minced with scissors after removal of visible fat and connective tissue, and cell suspensions were prepared by digestion in $10 \mathrm{ml}$ (per $\approx 100 \mathrm{mg}$ minced tissue) $1 \mathrm{mg} / \mathrm{ml}$ collagenase (Sigma Chemical Co., St Louis, MO, USA), $0.05 \mathrm{mg} / \mathrm{ml}$ DNase (Sigma), 1.5\% bovine serum albumin (BSA, Sigma) and $1.25 \mathrm{mM} \mathrm{Ca}^{2+}$ at $37^{\circ} \mathrm{C}$ (Rudberg et al. 1986). After digestion in a shaking incubator at 300 r.p.m. for 20-30 min, the suspensions were exposed to $1 \mathrm{mM}$
EGTA in $25 \mathrm{mM}$ Hepes buffer (pH 7.4) containing $142 \mathrm{mM} \mathrm{NaCl}$ and $6.7 \mathrm{mM} \mathrm{KCl}$ during $10 \mathrm{~s}$. Dead cells and debris were removed by centrifugation ( $5 \mathrm{~min}$; $300 \times \boldsymbol{g}$ ) through $25 \%$ standard isotonic Percoll (Pharmacia-Upjohn, Uppsala, Sweden) diluted in phosphate-buffered saline. Cell viability as determined by Trypan blue exclusion routinely exceeded 95\%. This procedure generally yielded small clusters of 2-20 cells, that were cultured in serum-free keratinocyte medium containing $0.09 \mathrm{mM}$ calcium, in which $5 \mathrm{ng} / \mathrm{ml}$ epidermal growth factor and $50 \mu \mathrm{g} / \mathrm{ml}$ bovine pituitary extract supplied from the manufacturer (Gibco, Uxbridge, UK) were added. For comparison, parallel batches of dispersed cells were cultured in Dulbecco's modified essential medium (DMEM) (Gibco; ionized calcium concentration $1.8 \mathrm{mM})$ containing $10 \%$ fetal calf serum (Gibco).

Cells were cultured in regular $25 \mathrm{~cm}^{2}$ cell culture flasks, in plastic 6-well plates $\left(0.5 \times 10^{6}\right.$ cells/well; Nunclon, Lincoln Park, NJ, USA) for $\left[{ }^{3} \mathrm{H}\right]$ thymidine incorporation experiments or in plastic $4 \mathrm{~cm}$ dishes $\left(1 \times 10^{6}\right.$ cells/dish $)$ for immunostaining. HeLa cells (American Type Culture Collection, Rockville, MD, USA) were used as positive controls in immunohistochemical studies (see below).

\section{$\left[{ }^{3} H\right]$ Thymidine incorporation test}

After overnight recovery, cells were fed and exposed to different concentrations of calcium $(0 \cdot 09,1 \cdot 25$ or $3.0 \mathrm{mM}$ ), all-trans-retinoic acid (atRA; Sigma), 9-cis retinoic acid (9cRA; Sigma) or $1,25(\mathrm{OH})_{2} \mathrm{D}_{3}$ (Leo-Pharma, Copenhagen, Denmark) (all compounds added to final concentrations of 10-1000 nM). Vehicle (ethanol) was added in control wells, and all cells were incubated for $48 \mathrm{~h}$, before adding fresh medium containing $1 \mu \mathrm{Ci}\left[{ }^{3} \mathrm{H}\right]$ thymidine/well. After another 12-h incubation, medium was aspirated and unspecifically incorporated $\left[{ }^{3} \mathrm{H}\right]$ thymidine precipitated by adding $500 \mu \mathrm{l}$ $10 \%$ trichloracetic acid for $20 \mathrm{~min}$ with the plates on ice. The precipitated material was discarded and the procedure repeated twice, before lysing the cells with $500 \mu \mathrm{l} 0 \cdot 5 \mathrm{M}$ $\mathrm{NaOH}$ and $0.5 \%$ Triton X-100/well. Radioactivity was monitored in a $\beta$-counter.

\section{Immunohistochemistry}

Immunohistochemistry was utilized for identification of cultured cells and characterization of proliferation rate. Immediately after plating and after a defined number of days (up to 60), cells were fixed in 50\% acetone for $2 \mathrm{~min}$ followed by $100 \%$ acetone for another $2 \mathrm{~min}$. For identification of cultured cells, the mouse monoclonal antibody E11 $(10 \mu \mathrm{g} / \mathrm{ml})$ directed against LRP2/megalin, and the rabbit antiserum IHC 610 (1:700; Peninsula Laboratories, Belmont, CA, USA) directed against PTH(1-34), were utilized. Both LRP2/megalin and PTH are highly 
expressed in parathyroid chief cells and are absent in endothelial cells and fibroblasts. In addition, based on earlier assumptions that expression of LRP2/megalin is reduced in proliferating and lower differentiated cells, the percentage of LRP2/megalin positive cells was monitored at different stages during culture. For characterization of proliferation rate, cells fixed with $4 \%$ formalin for $2 \mathrm{~min}$ and ethanol for another $10 \mathrm{~min}$ were evaluated for expression of proliferating cell nuclear antigen (PCNA) utilizing the PC10 antibody (1:100, DAKO, Glostrup, Denmark) as described earlier (Yamaguchi et al. 1997). In these cultures, after recovery overnight, cells were exposed to 10-1000 $\mathrm{nM}$ atRA, 9cRA and $1,25(\mathrm{OH})_{2} \mathrm{D}_{3}$ as above for $48 \mathrm{~h}$. All immunostainings involved usage of the peroxidase-antiperoxidase procedure, i.e. exposure of cells to $1 \% \mathrm{H}_{2} \mathrm{O}_{2}$ for $30 \mathrm{~min}$ followed by $10 \%$ normal swine or rabbit serum for $30 \mathrm{~min}$. After rinsing in PBS, the cells were incubated with the respective antibody/antiserum for $30 \mathrm{~min}$, followed by a secondary anti-mouse antibody (1:40, DAKO) and peroxidase-antiperoxidase complex (1:250, DAKO) for $30 \mathrm{~min}$ respectively. Immunostaining was visualized with 3-amino-9-ethyl-carbazole and counterstaining was performed with Mayer's hematoxylin. Parathyroid chief cells were identified by a cell surface staining of LRP2/megalin and/or cytoplasmic PTH reactivity. For PCNA expression intense nuclear staining was considered positive, and HeLa cells were used as a positive control. The percentage of PCNA positive cells was estimated by two independent observers, blind to the incubation protocol, by calculating the average ratio of stained cells in five randomly chosen areas. Each calculation was performed three times, and there was no significant intra- or interobserver variability.

\section{Cell counting}

Five hundred thousand cells were plated and cultured in triplicate with identical additions to the medium as for $\left[{ }^{3} \mathrm{H}\right]$ thymidine incorporation. Cells were cultured for $48 \mathrm{~h}$, trypsinized and, blind to the incubation protocol, counted in a hemocytometer.

\section{Functional analyses}

Investigations of PTH release from plated cells incubated as above and after different durations of culture were performed as previously described (Ridefelt et al. 1992). In brief, cells from six different patients were incubated at $37^{\circ} \mathrm{C}$ in duplicate in a buffer containing $20 \mathrm{mM}$ Hepes $(\mathrm{pH} 7 \cdot 4)$ at different calcium concentrations $(0 \cdot 5,1 \cdot 25$ and $3.0 \mathrm{mM}$ ) for $1 \mathrm{~h}$. Supernatants were recovered, and PTH(1-34) was analyzed by radioimmunoassay (Ridefelt et al. 1992), and intact PTH(1-84) by an immunoradiometric method (Nichol's Institute). Analyses of PTH were correlated to the amount of cells by determining the total protein amount in each well (Bio-Rad, Stockholm,
Sweden). PTH release at $0.5 \mathrm{mmol} / 1$ was set to $100 \%$, and maximal inhibition of PTH release was seen at an external $\mathrm{Ca}^{2+}$ concentration of $3.0 \mathrm{mmol} / \mathrm{l}$, i.e. further increases in external $\mathrm{Ca}^{2+}$ did not additionally reduce PTH secretion in these cells. The external $\mathrm{Ca}^{2+}$ concentration at which $50 \%$ of the reduction of PTH release between 0.5 and $3.0 \mathrm{mmol} / 1$ occurred was defined as set-point ${ }_{\mathrm{p}}$.

Cells were also cultured on glass cover-slips and incubated with fura- 2 acetoxymethylester for $30 \mathrm{~min}$ at $37^{\circ} \mathrm{C}$, as described (Johansson et al. 1987). The concentrations of intracellular calcium $\left(\left[\mathrm{Ca}^{2+}\right]_{\mathrm{i}}\right)$ were determined in small clusters of cells in a dual wavelength fluorescence microscope (Nikon, Tokyo, Japan), with emission at $510 \mathrm{~nm}$ and excitation at 340 and $380 \mathrm{~nm}$ during various additions of calcium to the perfusion medium.

The external calcium concentration at which halfmaximal stimulation of $\left[\mathrm{Ca}^{2+}\right]_{i}$ occurred (set-point ${ }_{c}$ ) was also calculated as a measure of calcium sensing function and was presumed to correlate to the differentiation state of the cells. In these experiments step-wise increases of external $\mathrm{Ca}^{2+}$ from $0 \cdot 5$ to $1 \cdot 0,1 \cdot 5,2 \cdot 0,2 \cdot 5$ and $3 \cdot 0 \mathrm{mM}$ were performed, and $\left[\mathrm{Ca}^{2+}\right]_{\mathrm{i}}$ calculated at each point (Fig. 1). Since no further increase in $\left[\mathrm{Ca}^{2+}\right]_{\mathrm{i}}$ occurred when increasing external $\mathrm{Ca}^{2+}$ to more than $3 \cdot 0 \mathrm{mM}$, this was set as the maximum stimulation. Cells were also preincubated with $10-1000 \mathrm{nM}$ vitamin $\mathrm{D}_{3}$, atRA or 9cRA, alone or in combinations for 2 days, during the $\mathrm{P} 0$ and $\mathrm{P} 1$ passages, for determination of possible effects on set-points. Additionally 100 or $1000 \mathrm{nM}$ vitamin $\mathrm{D}_{3}$, atRA or 9cRA were added to fura-2-loaded cells placed in the microfluorimeter in order to document possible acute effects on $\left[\mathrm{Ca}^{2+}\right]_{\mathrm{i}}$. Control cells were incubated with vehicle alone.

\section{Statistical analysis}

Paired, two-tailed Student's $t$-test and ANOVA were utilized, and $P<0.05$ was considered significant. Values are presented as means \pm s.E.M. (standard error of the mean).

\section{Results}

\section{Cell culture and basal functions}

More than 95\% of the dispersed cells consisted of typical parathyroid cells, as revealed by immunostaining with the anti-PTH and/or anti-LRP2/megalin antibodies. Only occasional fibroblasts were seen. After culture in DMEM/ $10 \%$ FCS the ratio of fibroblasts increased to an average of $10 \%(n=5)$ after 2 days, $17 \%$ after 3 days, and 50\% after 5 days and demonstrated the typical spindle shaped appearance, not positive for $\mathrm{PTH}$ or LRP2/megalin on immunostaining. During this culture, signs of proliferation of the PTH- and LRP2/megalin-expressing parathyroid chief cells were evident only during the first 1-2 days. 


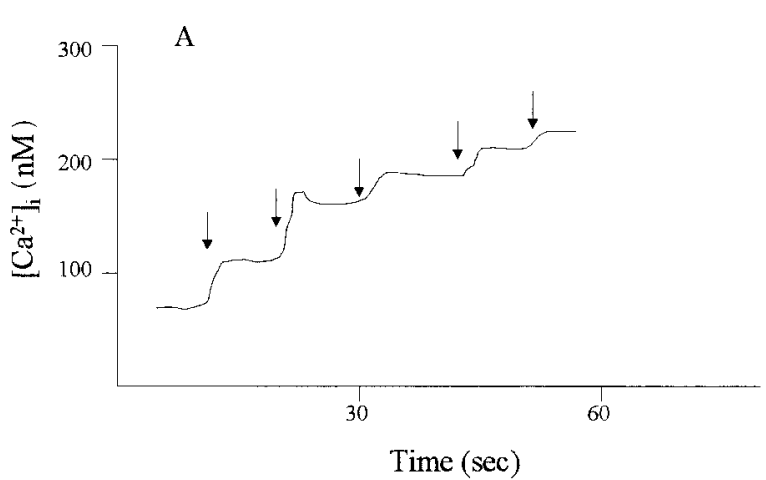

B

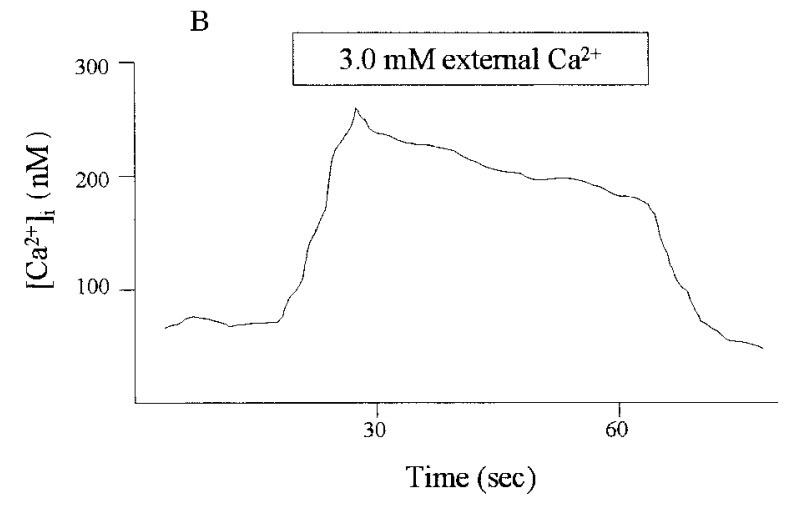

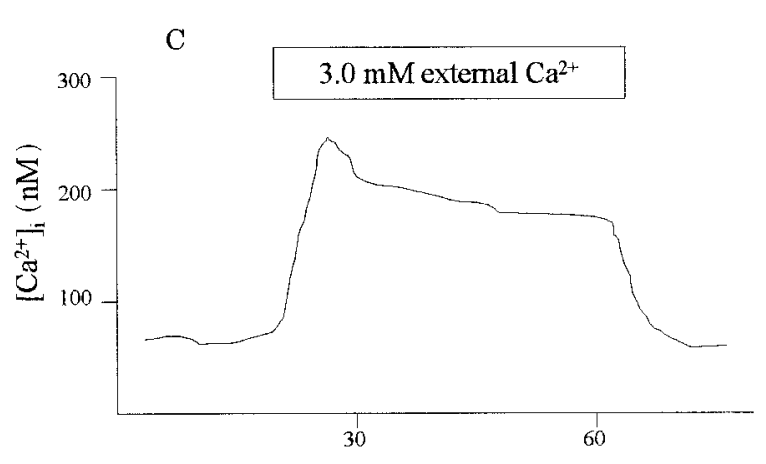

Time (sec)

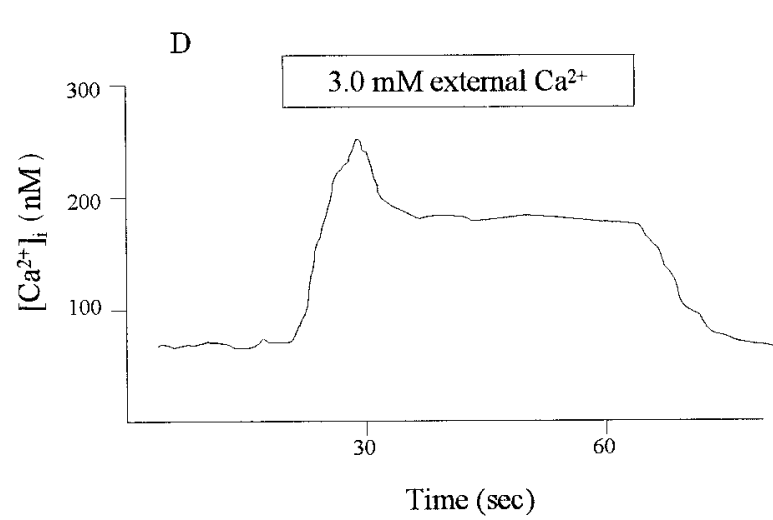

Figure 1 Microfluorimetry of a fura-2-loaded cluster of 4 cells. (A) Set-point $c_{c}$ estimated after step-wise increases of external Ca ${ }^{2}$ from $0 \cdot 5$ to $1 \cdot 0,1 \cdot 5,2 \cdot 0,2 \cdot 5$ and finally to $3.0 \mathrm{mM}$ (external $\mathrm{Ca}^{2}$ concentration increased $0.5 \mathrm{mM}$ at each arrow). $\left[\mathrm{Ca}^{2}\right]_{\mathrm{i}}$ was calculated at each concentration and the external $\mathrm{Ca}^{2}$ concentration at which $50 \%$ increase in $\left[\mathrm{Ca}^{2}\right]_{\mathrm{i}}$ occurred was defined as set-point ${ }_{\mathrm{C}}$. $(\mathrm{B}-\mathrm{D})\left[\mathrm{Ca}{ }^{2}\right]_{\mathrm{i}}$ response of (B) fura-2-loaded cell directly after dispersion, (C) in cell after 2 days in P0, and (D) in cell cultured for 10 days in P1. All cells $(\mathrm{B}, \mathrm{C}, \mathrm{D})$ were initially incubated in buffer containing $0.5 \mathrm{mM}$ external $\mathrm{Ca}^{2}$, and the concentration was suddenly increased to $3.0 \mathrm{mM}$ as indicated in each figure. Actual concentrations of $\left.\left[\mathrm{Ca}^{2+}\right]_{\mathrm{i}}\right)$ were calculated as indicated in Materials and Methods.

From the third day of culture in DMEM/10\% FCS no further increase in numbers of parathyroid cells was detected, which correlated with the time when proliferation of fibroblasts increased dramatically. After 10 days of culture, no LRP2/megalin or PTH positive cells were seen, and virtually all cells were fibroblasts, which proliferated until confluent.

On the other hand, during culture in the serum-free, low calcium-containing medium, most cells were expressing LRP2/megalin and PTH, and only occasional fibroblasts could be detected throughout culture up to 60 days. Even though $>95 \%$ of dispersed and plated cells demonstrated positive immunostaining with LRP2/megalin and $\mathrm{PTH}$, this had reduced to an average of $82 \pm 12 \%(n=5)$ after 2 days. There were no statistically significant differences in the ratio of cells positive for LRP2/megalin staining throughout the culture, even in further passages (see below). The cells were viable for up to 60 days in culture, as assessed by Trypan blue exclusion, ability to secrete PTH, and to respond with changes in $\left[\mathrm{Ca}^{2+}\right]_{\mathrm{i}}$ upon increases in external $\mathrm{Ca}^{2+}$.
The characteristic $\mathrm{Ca}^{2+}$ responsiveness of parathyroid cells was maintained during culture. In acutely dispersed cells, and in those incubated for 2 days in serum-free medium, incubation for $60 \mathrm{~min}$ in high external calcium $(3 \cdot 0 \mathrm{mM})$ inhibited $\mathrm{PTH}(1-34)$ secretion by $37 \cdot 1 \pm 3 \cdot 8 \%$ and $34 \cdot 5 \pm 3 \cdot 5 \%$ respectively compared with cells incubated with $0.5 \mathrm{mM}$ (Table 1). These numbers were achieved after correlating for the amount of parathyroid cells in each well by determining total protein content of the cells after the 60-min incubation. Similar results were seen when measuring PTH(1-84) concentrations in the medium. Moreover, acutely dispersed cells, as well as cells cultured for 2 days, also responded with a typical transient increase followed by a sustained increase in $\left[\mathrm{Ca}^{2+}\right]_{\mathrm{i}}$, when external calcium was raised from 0.5 to $3.0 \mathrm{mM}$ (Fig. 1). All examined cell clusters (acutely dispersed, $n=10$; after 2 days in culture, $n=10$ ) responded with similar patterns, indicating that this method is sensitive for identification of parathyroid cells.

The cultured cells proliferated, but only in the first flask, during the first passage (P0). Doubling time was estimated 
Table 1 Release of PTH(1-34) into the medium during culture at different $\mathrm{Ca}^{2+}$ concentrations (first 3 columns), the calculated secreted amounts of PTH(1-34) correlated to total protein concentration of the cells (4th column), calculation of set-point t $_{\mathrm{p}}$ (5th column), set-point (6th column), the peak $\left[\mathrm{Ca}^{2+}\right]_{\mathrm{i}}$ level after a sudden increase of external $\mathrm{Ca}^{2+}$ from 0.5 to $3.0 \mathrm{mM}\left(7\right.$ th column) and the $\left[\mathrm{Ca}^{2+}\right]_{\mathrm{i}}$ level of the sustained plateau (8th column) are depicted. Values in acutely dispersed cells, in P0 cells after 2 days culture, in cells in P0 after 2 days of culture with additions of $100 \mathrm{nM}$ vitamin $\mathrm{D}_{3}$, atRA or 9cRA, alone or in combinations, in P1 cells after 2 days of culture, and in P1 cells after 2 days of culture with additions of $100 \mathrm{nM}$ vitamin $\mathrm{D}_{3}$, atRA, or 9cRA are presented. The treated P0 and P1 cells are presented together, since no differences occurred between the different groups. Results in columns 2 and 3 are presented as the percentage of release at $0.5 \mathrm{mM}$ external $\mathrm{Ca}^{2+}$, set to $100 \%$ (column 1). Numbers of experiments being the basis for each result are indicated

\begin{tabular}{|c|c|c|c|c|c|c|c|c|}
\hline & $\begin{array}{l}\mathbf{0} \cdot 5 \mathbf{m M} \\
\mathrm{Ca}^{2+}(\%)\end{array}$ & $\begin{array}{l}\mathbf{1 \cdot 2 5} \mathbf{m M} \\
\mathrm{Ca}^{2+}(\%)\end{array}$ & $\begin{array}{l}3 \cdot 0 \mathbf{m M} \\
\mathbf{C a}^{2+}(\%)\end{array}$ & $\begin{array}{l}\text { PTH(1-34) } \\
\text { at } 0.5 \mathrm{mM}\end{array}$ & $\begin{array}{l}\text { Set-point } \\
(\mathrm{mM})\end{array}$ & $\begin{array}{l}\text { Set-point } \\
(\mathrm{mM})\end{array}$ & $\begin{array}{l}\text { Peak }\left[\mathrm{Ca}^{2+}\right]_{\mathbf{i}} \\
(\mathrm{nM})\end{array}$ & $\begin{array}{l}\text { Plateau }\left[\mathrm{Ca}^{2+}\right]_{\mathrm{i}} \\
(\mathrm{nM})\end{array}$ \\
\hline $\begin{array}{l}\text { Dispersed } \\
\text { cells }\end{array}$ & $\begin{array}{l}100 \\
n=10\end{array}$ & $85 \cdot 3 \pm 3 \cdot 5$ & $62 \cdot 9 \pm 3 \cdot 8$ & $77 \cdot 3 \pm 12$ & $1 \cdot 47 \pm 0 \cdot 16$ & $\begin{array}{l}1 \cdot 69 \pm 0 \cdot 35 \\
n=23\end{array}$ & $\begin{array}{l}247 \pm 12 \\
n=12\end{array}$ & $199 \pm 8$ \\
\hline P0 & $\begin{array}{l}100 \\
n=5\end{array}$ & $88 \cdot 8 \pm 3 \cdot 9$ & $65 \cdot 5 \pm 3 \cdot 5$ & $71 \cdot 1 \pm 9$ & $1 \cdot 53 \pm 0 \cdot 31$ & $\begin{array}{l}1 \cdot 77 \pm 0 \cdot 33 \\
n=12\end{array}$ & $\begin{array}{l}221 \pm 13 \\
n=14\end{array}$ & $165 \pm 22^{*}$ \\
\hline $\begin{array}{l}\mathrm{P} 0+ \\
\text { treatment }\end{array}$ & $\begin{array}{l}100 \\
n=4\end{array}$ & $82 \cdot 5 \pm 5 \cdot 3$ & $51 \pm 4$ & $72 \cdot 2 \pm 7$ & $1 \cdot 43 \pm 0 \cdot 21 \dagger$ & $\begin{array}{l}1 \cdot 62 \pm 0 \cdot 41 \dagger \\
n=6\end{array}$ & & \\
\hline P1 & $\begin{array}{l}100 \\
n=4\end{array}$ & $81 \cdot 0 \pm 3 \cdot 2^{*}$ & $52 \cdot 2 \pm 3 \cdot 9^{*}$ & $53 \cdot 5 \pm 7$ & $1 \cdot 33 \pm 0 \cdot 40^{*}$ & $\begin{array}{l}1 \cdot 49 \pm 0 \cdot 14^{*} \\
n=21\end{array}$ & $\begin{array}{l}284 \pm 8^{*} \\
n=11\end{array}$ & $225 \pm 11^{*}$ \\
\hline $\begin{array}{l}\mathrm{P} 1+ \\
\text { treatment }\end{array}$ & $\begin{array}{l}100 \\
n=4\end{array}$ & $79 \cdot 8 \pm 4 \cdot 1^{*}$ & $55 \cdot 1 \pm 4 \cdot 2^{*}$ & $57 \cdot 9 \pm 5 \cdot 9$ & $1 \cdot 37 \pm 0 \cdot 51^{*}$ & $\begin{array}{l}1 \cdot 45 \pm 0 \cdot 21^{*} \\
n=15\end{array}$ & & \\
\hline
\end{tabular}

*Indicates significant changes compared to both acutely dispersed and P0 cells; tindicates significant difference compared with untreated P0 cells only.

to be approximately 4 days. However, even though the cells ceased to proliferate when transferred to the second flask, they maintained the ability to respond with the typical biphasic rise in $\left[\mathrm{Ca}^{2+}\right]_{\mathrm{i}}$ upon increments in external calcium for up to 60 days of continuous culture (Fig. 1). Calcium also inhibited PTH release in cells during P1, and numbers were adjusted to total protein contents of the investigated cell masses (Table 1). Again, no differences were seen between concentrations of $\mathrm{PTH}(1-34)$ and PTH(1-84).

Tendencies towards, albeit not significant, higher setpoint $_{\mathrm{p}}$ and set-point ${ }_{\mathrm{c}}$ were seen in P0 cells compared with acutely dispersed cells (Table 1). Moreover, the peak $\left[\mathrm{Ca}^{2+}\right]_{\mathrm{i}}$ as well as the sustained plateau $\left[\mathrm{Ca}^{2+}\right]_{\mathrm{i}}$ levels after increasing external $\mathrm{Ca}^{2+}$ from 0.5 to $3.0 \mathrm{mM}$ were lower in P0 cells compared with acutely dispersed cells. However, cells in P1 passage demonstrated a significant leftshift in their set-point, 2 days after plating in this flask (Table 1). Also set-point ${ }_{c}$ was shifted to the left, and peak and sustained $\left[\mathrm{Ca}^{2+}\right]_{\mathrm{i}}$ levels increased during P1. These changes occurred within the first 2 days in P1, and were maintained for the 60 days monitored in this study. Treatment with $100 \mathrm{nM}$ vitamin $\mathrm{D}_{3}$, atRA or 9cRA for 2 days in $\mathrm{P} 0$, alone or in combinations, caused set-point left-shifts, but did not alter set-points after treatment in P1 (Table 1). Since there were no differences between the various treatments in the degree of left-shift, they are presented together in Table 1.

$\left[\mathrm{Ca}^{2+}\right]_{\mathrm{i}}$ remained unchanged up to $20 \mathrm{~min}$ after adding 100 or $1000 \mu \mathrm{M} 1,25$-dihydroxyvitamin $\mathrm{D}_{3}$, atRA or 9cRA to cells examined directly after dispersion, after 2 days in $\mathrm{P} 0$, or after 10 days in $\mathrm{P} 1$, and at $0.5 \mathrm{mM}$ external $\mathrm{Ca}^{2+}$.

\section{Effects on proliferation}

Proliferation studies were performed during the P0 passage. $\left[{ }^{3} \mathrm{H}\right]$ Thymidine incorporation demonstrated that low ambient calcium $(0.09 \mathrm{mM})$ stimulated human parathyroid cell proliferation (Fig. 2). Additions of 10-1000 nM atRA, 9cRA and vitamin $\mathrm{D}_{3}$ were therefore performed at this external calcium concentration. All these compounds dose-dependently inhibited low calciumstimulated parathyroid cell proliferation, and significant inhibition was achieved at 100 and $1000 \mathrm{nM}$ (Fig. 3). Cell counting experiments as well as immunostaining for PCNA gave similar results as the $\left[{ }^{3} \mathrm{H}\right]$ thymidine incorporation data (Fig. 3). On average $11 \cdot 2 \pm 7 \%$ of the acutely dispersed cells demonstrated intense PCNA immunostaining (Fig. 4). This ratio was increased to $29 \cdot 8 \pm 9 \%$ in $\mathrm{P} 0$, and reduced to $1 \cdot 3 \pm 1 \%$ in $\mathrm{P} 1$. A tendency to, albeit not significant, additive effects were seen with combinations of vitamin $\mathrm{D}_{3}$ with atRA or 9cRA in the PCNA experiments during $\mathrm{P} 0$, while this could not be noted in $\left[{ }^{3} \mathrm{H}\right]$ thymidine incorporation or cell counting experiments (Fig. 3). Concomitantly as proliferation was inhibited, left-shifts in set-points occurred (see above; Table 1).

\section{Discussion}

Many attempts to establish parathyroid cells in culture and parathyroid cell lines have been undertaken, but only occasional reports have indicated success (Brandi et al. 1986, Roussanne et al. 1998) and it has been difficult to repeat some of these data. Most attempts were performed utilizing bovine parathyroid cells, whereas our aim was to culture human parathyroid cells obtained from parathyroid 


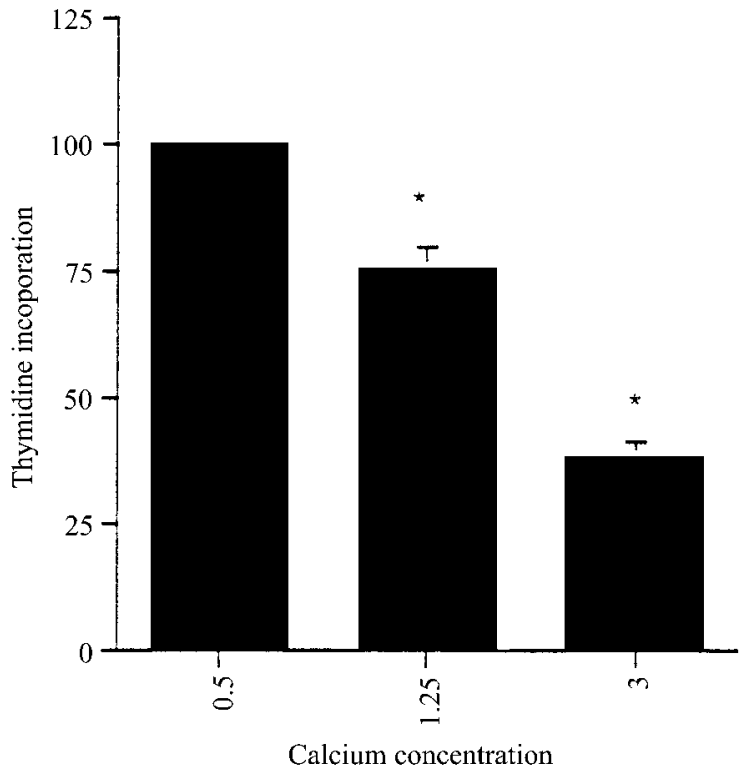

Figure 2 Effect of calcium on parathyroid chief cell proliferation determined by $\left[{ }^{3} \mathrm{H}\right]$ thymidine incorporation. Data are presented as a percentage of radioactivity ( \pm S.E.M.) monitored by $\beta$-scintillation after incubation at $0.5,1.25$ and $3.0 \mathrm{mM}$ external calcium. ${ }^{*} P<0.05$ compared with incubation at $0.5 \mathrm{mM}$.

adenomas. Based on experience with various growth factor combinations (Ridefelt et al. 1995), we tried to optimize the medium for culture of human parathyroid cells. Our results show that a defined serum-free medium originally prepared for keratinocyte culture is suitable for human parathyroid cells, which are found to proliferate until confluent in this medium, although proliferation is hampered by further subculture. In this medium no fibroblast overgrowth occurs, possibly related to the low ambient $\mathrm{Ca}^{2+}$ concentration and the serum-free conditions. Parathyroid cells cultured in this medium are viable and respond with adequate changes in $\left[\mathrm{Ca}^{2+}\right]_{\mathrm{i}}$ upon alteration of external calcium during the proliferative as well as the quiescent phase. The response is characterized by a transient elevation followed by a sustained rise of $\left[\mathrm{Ca}^{2+}\right]_{\mathrm{i}}$ after challenging the cells with a sudden increase in external $\mathrm{Ca}^{2+}$. This response is similar to the one previously reported from bovine and human parathyroid cells (Johansson et al. 1987, 1989, Ridefelt et al. 1996). We have earlier also demonstrated oscillatory responses in $\left[\mathrm{Ca}^{2+}\right]_{\mathrm{i}}$ using a growth cocktail supplemented medium (Ridefelt et al. 1995), but such responses do not occur using the present protocol. This further emphasizes how the culture conditions influence the function of parathyroid cells, and the difficulties in interpreting data obtained from parathyroid cell cultures when trying to extrapolate them into the in vivo situation. Nevertheless, the present protocol offers a possibility to study proliferating human parathyroid cells which during the culture vary their differentiation level and express different sensitivity to external $\mathrm{Ca}^{2+}$.

The proliferating $\mathrm{P} 0$ cells demonstrated similar setpoints as the acutely dispersed cells, while the quiescent P1 cells exhibited left shifts in both set-point $t_{p}$ and set-point ${ }_{c}$, as well as increased peak and sustained levels of $\left[\mathrm{Ca}^{2+}\right]_{i}$ after a sudden increase from 0.5 to $3.0 \mathrm{mM}$ external $\mathrm{Ca}^{2+}$. These observations correlate in time with the proliferative state of the cells, i.e. the acutely dispersed cells and the proliferating P0 cells demonstrate similarly right-shifted set-points, while the not dividing $\mathrm{P} 1$ cells demonstrate left-shifts. This is further emphasized by the left-shifted set-points, albeit not to a similar degree, in P0 cells incubated for $48 \mathrm{~h}$ with vitamin $\mathrm{D}_{3}$, atRA or 9cRA, where proliferation is also inhibited concomitantly. This phenomenon may reflect a differentiating event in these cells, coupled to the reduced proliferative rate. This observation is the first where signs of increased differentiation occur in parathyroid cells. However, whether the added compounds primarily affect proliferation and whether set-point changes are secondary events, is not clear. One possible explanation for a direct effect on set-points would be increased expression of calcium receptors, CaR and/or LRP2/megalin. Even though LRP2/megalin expression was down-regulated, CaR expression was maintained in human parathyroid cells cultured by Roussanne et al. (1998). Our own and other authors' previous data from bovine parathyroid cells indicate that vitamin $\mathrm{D}_{3}$, atRA and 9cRA do not affect $\mathrm{CaR}$ or LRP2/megalin mRNA expression (Rogers et al. 1995, Brown et al. 1996, Hellman et al. 1998). Nevertheless, these compounds may still affect CaR as well as LRP2/ megalin expression in human pathological cells. In the present study attempts to measure possible variations in LRP2/megalin expression failed during culture, possibly due to the relatively insensitive immunohistochemical method used. Therefore, to find a molecular explanation for the left-shifted set-point and to discover whether it is a primary or secondary event, in situ hybridizations, RNAse protection assays or quantitative PCR utilizing probes encoding for $\mathrm{CaR}$ and LRP2/megalin may be more informative.

We have previously reported that a certain polymorphic variation in the vitamin $\mathrm{D}$ receptor gene is associated with a higher incidence of HPT and right-shifted set-points in postmenopausal women (Carling et al. 1995, 1997). Therefore the reduced inhibitory effect of vitamin $\mathrm{D}_{3}$ may be determined not only by low levels of circulating vitamin $\mathrm{D}_{3}$, but also by the presence of the polymorphic variant $b a T$ of the VDR gene. A relative lack of vitamin $\mathrm{D}_{3}$ may thus occur in some individuals although serum levels of vitamin $\mathrm{D}_{3}$ are normal. In the present series the inhibitory effect of vitamin $\mathrm{D}_{3}$ (and retinoids) on $\mathrm{PTH}$ release is documented at low external $\mathrm{Ca}^{2+}$ concentrations. This implies that at high external $\mathrm{Ca}^{2+}$ concentrations such as in HPT, this effect would be of minor importance. 

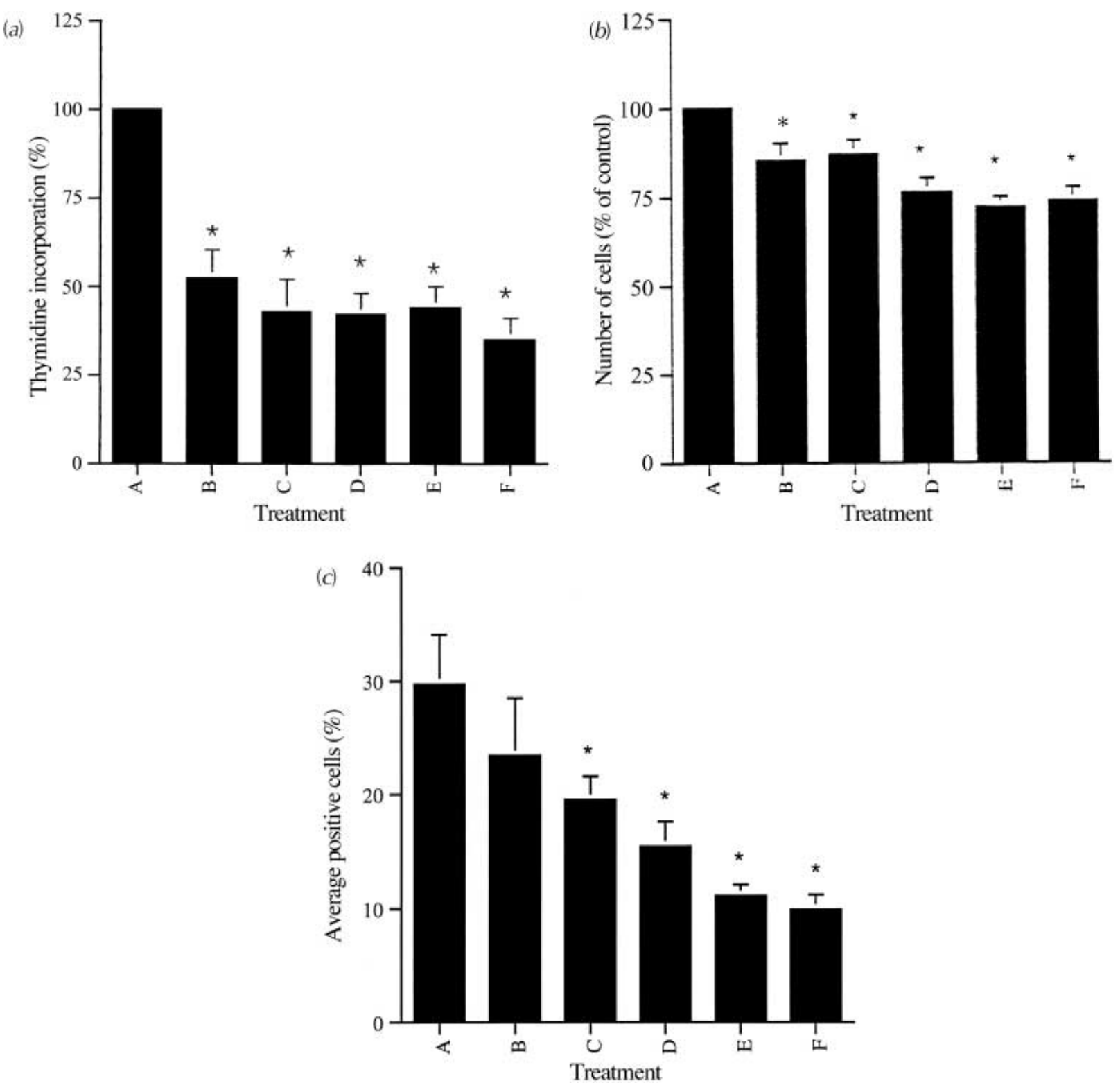

Figure 3 (a) Effect of vehicle alone (A) or addition of $100 \mathrm{nM}$ atRA (B), 9cRA (C), vitamin $D_{3}(\mathrm{D})$, atRA and vitamin $\mathrm{D}_{3}$ (E) or 9cRA and vitamin $D_{3}(F)$ on parathyroid chief cell proliferation were determined by $\left[{ }^{3} \mathrm{H}\right]$ thymidine incorporation. Cells were cultured at $0 \cdot 09 \mathrm{mM}$ calcium. Data are presented as a percentage of radioactivity monitored by $\beta$-scintillation after incubation with vehicle. ${ }^{*} P<0 \cdot 05$ compared with (A). (b) Number of cells remaining after $48 \mathrm{~h}$ culture with vehicle alone (A) or the addition of $100 \mathrm{nM}$ atRA (B), 9cRA (C), vitamin $\mathrm{D}_{3}$ (D), atRA and vitamin $D_{3}(E)$ or $9 \mathrm{cRA}$ and vitamin $D_{3}(F)$. Data are presented as a percentage compared with control wells $(A)$. ${ }^{\star} P<0 \cdot 05$ compared with (A). (C) Average percentage of parathyroid chief cells positively immunostained by PCNA antibody after treatment with vehicle alone $(A)$ or addition of $100 \mathrm{nM}$ atRA $(B), 9 c R A(C)$, vitamin $D_{3}(D)$, atRA and vitamin $D_{3}(E)$ or $9 c R A$ and vitamin $D_{3}(F)$. ${ }^{*} P<0 \cdot 05$ compared with A.

Nevertheless, in patients with HPT secondary to uremia, levels of serum PTH decrease after initiation of vitamin $\mathrm{D}_{3}$ treatment (Slatopolsky et al. 1984). Increased levels of vitamin $\mathrm{D}_{3}$ may be needed in patients harboring the baT polymorphism in the VDR gene, and upregulation of VDR by vitamin D itself may be another explanation for the positive effect on PTH release seen at high external $\mathrm{Ca}^{2+}$ concentrations.

In accordance with previous in vitro and in vivo studies (Brandi et al. 1986, Naveh-Many et al. 1995) we found that low external calcium concentrations $(0.5 \mathrm{mM})$ induced parathyroid cell proliferation, whereas culture 


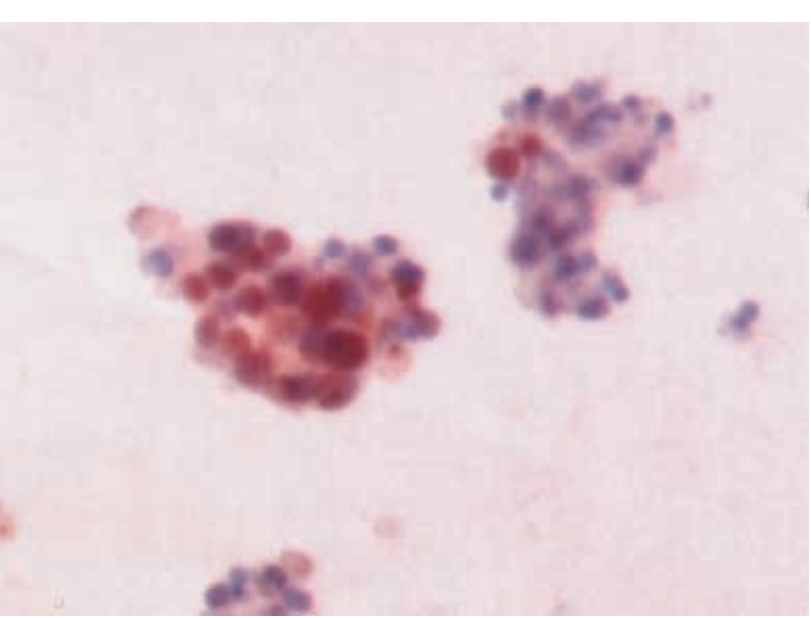

Figure 4 Immunohistochemical staining of cultured parathyroid chief cells, fixed with $4 \%$ formalin for 2 min and ethanol for $10 \mathrm{~min}$, and further subjected to a peroxidase-antiperoxidase immunostaining procedure using the PC10 antibody (1:100) against PCNA. Nuclear staining is considered positive. Magnification $\times 150$.

at $3.0 \mathrm{mM}$ ambient calcium significantly reduced cell proliferation. Moreover, we found significant inhibition of cell proliferation resulting in lower cell numbers after treatment with vitamin $\mathrm{D}_{3}$, atRA or 9cRA. Previous studies have mostly indicated an inhibitory effect of vitamin $\mathrm{D}_{3}$ on parathyroid cell proliferation (Slatopolsky et al. 1984, Szabo et al. 1989), although a lack of effect has also been reported (Naveh-Many et al. 1995), whereas effects of retinoic acids have not been evaluated.

Retinoic acids bind to cytoplasmic transport proteins and subsequently to nuclear receptors present in parathyroid tissue (Liu et al. 1996). The nuclear receptors for vitamin $\mathrm{D}_{3}$ and retinoic acids ( $\mathrm{RAR}, \mathrm{RXR}$ ) form heterodimers, and different effects of these complexes have been documented. Thus, 9cRA binding to an RXR/ VDR heterodimer may inhibit or promote the vitamin $\mathrm{D}_{3} / \mathrm{VDR}$ effect on genomic transcription rate (Carlberg et al. 1993, Schrader et al. 1993). It has recently been demonstrated that 9cRA and atRA have similar effects on PTH mRNA expression as vitamin $\mathrm{D}_{3}$ and thereby suppress PTH release (MacDonald et al. 1994, Liu et al. 1996). However, this effect may be indirect, since no actual RAR or RXR binding sites seem to be present in the PTH gene promoter region ( $G$ Westin, personal communication). As demonstrated in the present study, the effects of vitamin $D_{3}$ and retinoids seem to include inhibition of parathyroid chief cell proliferation. Molecular mechanisms for the effect of vitamin $\mathrm{D}_{3}$ on parathyroid cell proliferation may include the c-myc gene (Kremer et al. 1989). Retinoic acids have previously been shown to affect proliferation of many tumor cell lines, and the mechanisms for such effects may be several (Nagy et al. 1998, Singh \& Lippman 1998).
The present study utilizes a successful protocol with serum-free, low-calcium conditions for culture of human parathyroid cells obtained from adenomas. The previous method of Roussanne et al. (1998) utilized cells derived from patients with uremic hyperparathyroidism, and highphosphate serum containing medium, which also resulted in proliferating human parathyroid cells. Thus, it is possible to obtain dividing human parathyroid cell cultures, which may be used for a number of interesting studies. Our protocol offers studies of parathyroid cells during a dedifferentiated proliferative phase as well as a putatively more differentiated non-proliferative phase. For the first time we can demonstrate correlation between set-point/ differentiation level and proliferation in parathyroid cells. Although not the scope of this paper, changes in protein expression may be determined to characterize these events. This study concludes that not only vitamin $\mathrm{D}_{3}$, but also atRA and 9cRA inhibit chief cell proliferation, and that these compounds may increase calcium sensitivity/ induce differentiation during a proliferative phase, measured as increments in set-point $t_{p}$ and set-point ${ }_{c}$, as well as inhibit PTH release. Therefore, vitamin $\mathrm{D}_{3}$, which today is routinely used for the treatment of secondary HPT (or perhaps non-calcemic analogs) may also be used in primary HPT, especially in postmenopausal women. Moreover, retinoids or their analogs lacking unwanted side effects might also be considered for medical treatment of primary as well as secondary hyperparathyroidism.

\section{Acknowledgements}

The skilled assistance of Birgitta Bondeson is greatly acknowledged. This study was performed with support from the Tore Nilssons Foundation, the Swedish Society for Medical Research and the Swedish Medical Research Council, Swedish Cancer Foundation and Selander's Foundation.

\section{References}

Brandi ML, Fitzpatrick LA, Coon HG \& Aurbach GD 1986 Bovine parathyroid cells: cultures maintained for more than 140 population doublings. PNAS 83 1709-1713.

Brown E 1991 Extracellular $\mathrm{Ca}^{2+}$ sensing, regulation of parathyroid cell function, and role of $\mathrm{Ca}^{2+}$ and other ions as extracellular (first) messengers. Physiology Review 71 371-411.

Brown A, Zhong M, Finch J, Ritter C, McCracken R, Morrissey J \& Slatopolsky E 1996 Rat calcium-sensing receptor is regulated by vitamin D but not by calcium. American Journal of Physiology 270 F454-F460.

Brown EM, Gamba G, Riccardi D, Lombardi M, Butters R, Kifor O, Sun A, Hediger MA, Lytton J \& Hebert SC 1993 Cloning and characterization of an extracellular $\mathrm{Ca}\left({ }^{2+}\right)$-sensing receptor from bovine parathyroid. Nature 366 575-580.

Carlberg C, Bendik I, Wyss A, Meier E, Sturzenbecker LJ, Grippo JF \& Hunziker W 1993 Two nuclear signalling pathways for vitamin D. Nature $61657-660$. 
Carling T, Kindmark A, Hellman P, Lundgren E, Ljunghall S, Rastad J, Åkerström G \& Melhus H 1995 Vitamin D genotypes in hyperparathyroidism. Nature Medicine 1 1309-1311.

Carling T, Ridefelt P, Hellman P, Rastad J \& Åkerström G 1997 Vitamin D receptor polymorphisms correlate to parathyroid cell function in primary hyperparathyroidism. Journal of Clinical Endocrinology and Metabolism 72 1772-1775.

Christensen EI, Gliemann J \& Moestrup SK 1992 Renal tubule gp330 is a calcium binding receptor for endocytic uptake of protein. Journal of Histochemisty and Cytochemistry 40 1481-1490.

Demay MB, Kiernan MS, DeLuca HF \& Kronenberg HM 1992 Sequences in the human parathyroid hormone gene that bind the 1,25-dihydroxyvitamin $\mathrm{D}_{3}$ receptor and mediate transcriptional repression in response to 1,25-dihydroxyvitamin $\mathrm{D}_{3}$. PNAS $\mathbf{8 9}$ 8097-8101.

Farnebo F, Enberg E, Grimelius L, Bäckdahl M, Schalling M, Larsson C \& Farnebo L-O 1997 Tumor specific decreased expression of calcium sensing receptor message ribonucleic acid in sporadic primary hyperparathyroidism. Journal of Clinical Endocrinology and Metabolism 82 3481-3486.

Hellman P, Åkerström G, Juhlin C, Ridefelt P \& Rastad J 1994 Pathophysiology of hyperparathyroidism. In Current Controversy in Parathyroid Operation and Reoperation, pp 9-22. Eds G Åkerström, C Juhlin \& J Rastad. Austin, TX, USA: RG Landes Company.

Hellman P, Liu W, Törmä H \& Åkerström G 1998 Parathyroid cells are targets for retinoids. Bone $\mathbf{2 3} \mathrm{S} 452$.

Hjälm G, Murray E, Crumley G, Harazim W, Lundgren S, Onyango I, Ek B, Larsson M, Juhlin C, Hellman P, Davis H, Åkerström G, Rask L \& Morse B 1996 Cloning and sequencing of human gp330, a $\mathrm{Ca}^{2+}$ binding receptor with potential intracellular signalling properties. European Journal of Biochemistry 239 132-137.

Johansson H, Larsson R, Nygren P, Lindh E, Rastad J, Åkerström G \& Gylfe E 1987 Cytoplasmic $\mathrm{Ca}^{2+}$ concentration of single normal human and bovine parathyroid cells measured by dual wavelength microfluorometry. Bioscience Reports 7 705-712.

Johansson H, Rastad J, Bjerneroth G, Gylfe E \& Åkerström G 1989 Microfluorometric measurements of cytoplasmic calcium in chief and oxyphil parathyroid cells of adenomatous and hyperplastic glands and of normal-sized glands associated with adenomas. Surgery 106 517-524.

Juhlin C, Johansson H, Holmdahl R, Gylfe E, Larsson R, Rastad J, Åkerström G \& Klareskog L 1987 Monoclonal antiparathyroid antibodies interfering with a $\mathrm{Ca}^{2+}$-sensor of human parathyroid cells. Biochemical and Biophysical Research Communications 143 570-574.

Juhlin C, Klareskog L, Nygren P, Ljunghall S, Gylfe E, Rastad J \& Åkerström G 1988 Hyperparathyroidism is associated with reduced expression of a parathyroid calcium receptor mechanism defined by monoclonal antiparathyroid antibodies. Endocrinology 122 2999-3001.

Kifor O, Moore FD, Wang P, Goldstein M, Vassilev P, Kifor I, Hebert SC \& Brown EM 1996 Reduced immunostaining for the extracellular $\mathrm{Ca}^{2+}$-sensing receptor in primary and uremic secondary hyperparathyroidism. Journal of Clinical Endocrinology and Metabolism 81 1598-1606.

Kremer R, Bolivar I, Goltzman D \& Hendy GN 1989 Influence of calcium and 1,25-dihydroxycholecalciferol on proliferation and proto-oncogene expression in primary cultures of bovine parathyroid cells. Endocrinology 125 935-941.

Liu W, Hellman P, Li Q, Yu W-R, Juhlin C, Nordlinder H, Rollman O, Åkerström G, Törmä H \& Melhus H 1996 Biosynthesis and function of all-trans- and 9-cis-retinoic acid in parathyroid cells. Biochemical and Biophysical Research Communications 229 922-929.
MacDonald PN, Ritter C, Brown AJ \& Slatoposlky E 1994 Retinoic acid suppresses parathyroid hormone (PTH) secretion and preproPTH mRNA levels in bovine parathyroid cell culture. Journal of Clinical Investigation $\mathbf{9 3}$ 725-730.

Nagy L, Thomazy V, Heyman R \& Davis P 1998 Retinoid-induced apoptosis in normal and neoplastic tissues. Cell Death Differentiation 5 11-19.

Naveh-Many T, Rahamimov R, Livni N \& Silver J 1995 Parathyroid cell proliferation in normal and chronic renal failure rats. The effect of calcium, phosphate and vitamin D. Journal of Clinical Investigation 96 1786-1793.

Ridefelt P, Nygren P, Hellman P, Larsson R, Rastad J, Åkerström G \& Gylfe E 1992 Regulation of parathyroid hormone release in normal and pathological parathyroid cells exposed to modulators of protein kinase C. Acta Endocrinologica 126 505-509.

Ridefelt P, Björklund E, Åkerström G, Olsson MJ, Rastad J \& Gylfe E $1995 \mathrm{Ca}^{2+}$-induced $\mathrm{Ca}^{2+}$ oscillations in parathyroid cells. Biochemical and Biophysical Research Communications 215 903-909.

Ridefelt P, Rastad J, Åkerström G, Hellman P \& Gylfe E 1996 Imaging of $\mathrm{Ca}^{2+}$-induced cytoplasmic $\mathrm{Ca}^{2+}$ responses in normal and pathological parathyroid cells. European Journal of Clinical Investigation 26 1166-1170.

Rogers K, Dunn C, Conklin R, Hadfield S, Petty B, Brown E, Hebert S, Nemeth E \& Fox J 1995 Calcium receptor messenger ribonucleic acid levels in the parathyroid glands and kidney of vitamin D-deficient rats are not regulated by plasma calcium or 1,25-dihydroxyvitamin $\mathrm{D}_{3}$. Endocrinology 136 499-504.

Roussanne M-C, Gogusev J, Hory B, Duchambon P, Souberbielle JC, Nabarra B, Pierrat D, Sarfati E, Drüeke T \& Bourdeau A 1998 Persistence of $\mathrm{Ca}^{2+}$-sensing receptor expression in functionally active, long-term human parathyroid cell cultures. Journal of Bone and Mineral Research 13 354-362.

Rudberg C, Grimelius L, Johansson H, Ljunghall S, Odselius R, Pertoft H, Wide L \& Åkerström G 1986 Alterations in density, morphology and parathyroid hormone release of dispersed parathyroid cells from patients with hyperparathyroidism. Acta Pathologica Microbiologica Immunologica Scandinavica Section A 94 253-261.

Sakaguchi K, Santora A, Zimering M, Curcio F, Aurbach GD \& Brandi ML 1987 Functional epithelial cell line cloned from rat parathyroid glands. PNAS 84 3269-3273.

Schrader M, Bendik I, Becker-Andre M \& Carlberg C 1993 Interaction between retinoic acid and vitamin D signaling pathways. Journal of Biological Chemistry 268 17830-17836.

Singh D \& Lippman S 1998 Cancer chemoprevention. Part 1: retinoids and carotenoids and other classic oxidants. Oncology 12 1643-1653, 1657-1658.

Slatopolsky E, Weerts C, Thielan J, Horst R, Harter H \& Martin KJ 1984 Marked suppression of secondary hyperparathyroidism by intravenous administration of 1,25-dihydroxycholecalciferol in uremic patients. Journal of Clinical Investigation 74 2136-2143.

Szabo A, Merke J, Beier E, Mall G \& Ritz E 1989 1,25(OH) vitamin $\mathrm{D}_{3}$ inhibits parathyroid cell proliferation in experimental uremia. Kidney International 35 1049-1056.

Yamaguchi S, Yachiku S \& Morikawa M 1997 Analysis of proliferative activity of the parathyroid glands using proliferating cell nuclear antigen in patients with hyperparathyroidism. Journal of Clinical Endocrinology and Metabolism 82 2681-2688.

Received 20 March 2000

Revised manuscript received 20 October 2000 Accepted 1 November 2000 